\title{
KEDUDUKAN HUKUM PENGAMBILALIHAN TANAH WAKAF YANG BATAL DEMI HUKUM UNTUK DIBAGIKAN SEBAGAI HARTA WARISAN DALAM KAJIAN UNDANG-UNDANG NO. 41 TAHUN 2004 TENTANG WAKAF
}

\author{
Lambang Prasetyo
}

\begin{abstract}
ABSTRAK
Wakaf adalah perbuatan hukum seseorang atau badan hukum yang memisahkan sebagian dari harta kekayaan yang berupa tanah milik dan melembagakannya untuk selama-lamanya untuk kepentingan peribadatan atau keperluan umum lainnya sesuai dengan ajaran agama Islam. .

Tujuan penelitian ini adalah: Untuk memahami proses pengambilalihan tanah wakaf yang batal dalam hukum untuk dibagikan sebagai harta warisan dan kedudukan hukum pengambilalihan tanah wakaf yang batal dalam hukum untuk dibagikan sebagai harta warisan berdasarkan Undang-undang Nomor 41 Tahun 2004 tentang wakaf.

Metode penelitan yang digunakan dalam penelitian ini menggunakan pendekatan yuridis normatif, dengan spesifikasi deskriptif analitis. Sumber penelitian diperoleh dari bahan hukum primer dan sekunder dengan teknik pengumpulan melalui literature dan studi pustaka. Metode penyajian data melalui deskriptif,. Metode analisis bahan hukum dilakukan melalui analisis kualitatif.

Hasil penelitian menunjukkan bahwa : 1) Proses pengambilalihan tanah wakaf yang batal dalam hukum untuk dibagikan sebagai harta warisan dilaksanakan oleh Pengadilan Agama Semarang yaitu dengan menetapkan harta bersama wakif dengan istri wakif, selanjutnya menetapkan setengah dari harta bersama tersebut adalah bagian wakif yang belum dibagi waris sekaligus menetapkan para ahli waris dan bagian-bagiannya menurut pembagian pewarisan Islam. Hal ini sesuai dengan Pasal 97 Kompilasi Hukum Islam yang menyatakan bahwa wakif (duda) berhak atas seperdua dari harta bersama sepanjang tidak ditentukan lain dalam perjanjian perkawinan. 2) Kedudukan hukum pengambilalihan tanah wakaf yang batal dalam hukum untuk dibagikan sebagai harta warisan berdasarkan Undang-undang Nomor 41 Tahun 2004 tentang wakaf, Pada prinsipnyua UU No.41 Tahun 2004 menegaskan bahwa tanah wakif yang sudah diwakafkan tidak bisa dibatalkan, namun tentunya pronsip kepastian hokum tersbut harus bersinergi trerhadap nilai keadilankepada pewakif atau ahli waris . Di sinilah peran hakim dituntut memberikan keadilan yang seadilnya jika ditemukan sengketa wakaf.
\end{abstract}

Kata kunci : Pengambilalihan, Wakaf dan Warisan 


\title{
THE LEGAL STATUS OF WAKAF LAND ACQUISITION WHICH IS \\ CANCELED \\ BY LAW FOR BEING SHARED AS HERITAGE IN THE STUDY OF ACT NO. 41 YEAR 2004 ABOUT WAKAF
}

Lambang Prasetyo

\begin{abstract}
Wakaf is legal act of a person or legal entity that separates part of the property in the form of land property and institutionalize it forever for the sake of worship or other public purposes in accordance with the teachings of Islam.

The purpose of this study is: To understand the process of the acquisition of wakaf land which is canceled by law for being shared as heritage and the legal status of wakaf land acquisition which is canceled by law for being shared as heritage in accordance with Act No. 41 Year 2004 about wakaf.

The research methodology used in this study is juridical normative approach, with specification of analytic descriptive. The sources of the research are derived from the primary and secondary law materials with the technique of collection through the literature and library research. The method of data presentation is descriptive, the method of analyzing the law materals is done by using qualitative analysis.

The results of the research show that: 1) The process of acquisition of wakaf land that is canceled by law for being shared as inheritance is carried out by Semarang Religious Court by determining the joint property of wakif and the wakif's wife, then set half of the joint property is the wakif part which has not been shared and stated the heirs and their parts according to the provision of Islamic inheritance. This is in accordance with Article 97 of the Compilation of Islamic Law which states that the wakif (widower) should be given half of the common property as long as it is not specified otherwise in the marriage agreement. 2) Legal status of the acquisition of wakaf land which is canceled by law for being shared as inheritance based on Act No. 41 Year 2004 about wakaf, In principle, Act No.41 Year 2004 affirms that wakif's land that has been shared can not be canceled, but of course the principle of law certainty must synergize with the value of fairness to the perpetrator or heirs. This is where the role of the judges are required to provide fair justice if found wakaf case.
\end{abstract}

Keywords: Acquisition, Wakaf and Inheritance 


\section{PENDAHULUAN}

\section{A. Latar Belakang}

Wakaf sebagai salah satu anjuran ibadah yang dilaksanakan adalah komponen hubungan antara kaum muslim dengan Tuhan maupun dengan masyarakat. Wakaf adalah perbuatan hukum seseorang atan badan hukum yang memisahka sebagian dari harta kekayaan yang berupa tanah milik dan melembagakannya untuk selamalamanya untuk kepentingan peribadatan atau keperluan umum lainnya sesuai dengan ajaran agama Islam.

Wakaf merupakan suatu
peralihan hak atas tanah yang
bersandar pada hukum agama. ${ }^{2}$
Perwakafan tanah milik wakaf
adalah suatu lembaga keagamaan
yang dapat dimanfaatkan sebagai
salah satu sarana pembangunan dan
pengembangan kehidupan
keagamaan, khususnya bagi umat
Islam dalam rangka mencapai
kesejahteraan materiil dan spirituil
1 Rachmadi Usman, Hukum
Perwakafan Di Indonesia), (Jakarta: Sinar
Grafika, 2009), hlm. 121

menuju masyarakat adil dan makmur berdasarkan Pancasila.

Perwakafan tanah saat ini sebelum diatur dalam Hukum Agraria Nasional. Pelaksanan wakaf masih sangat sederhana yaitu cukup ditandai oleh adanya rasa kepercayaan dan terpenuhinya beberapa unsur dan syarat tertentu sesuai dengan ajaran hukum Islam, yaitu cukup diikrarkan di hadapan nadzir serta disaksikan oleh beberapa orang saksi. Sebagai akibatnya, sering tidak ada usaha pengadministrasian sama sekali atau hanya sampai pencatatan ke desa saja, tidak sampai pada instansi yang berwenang terhadap masalah pertanahan.

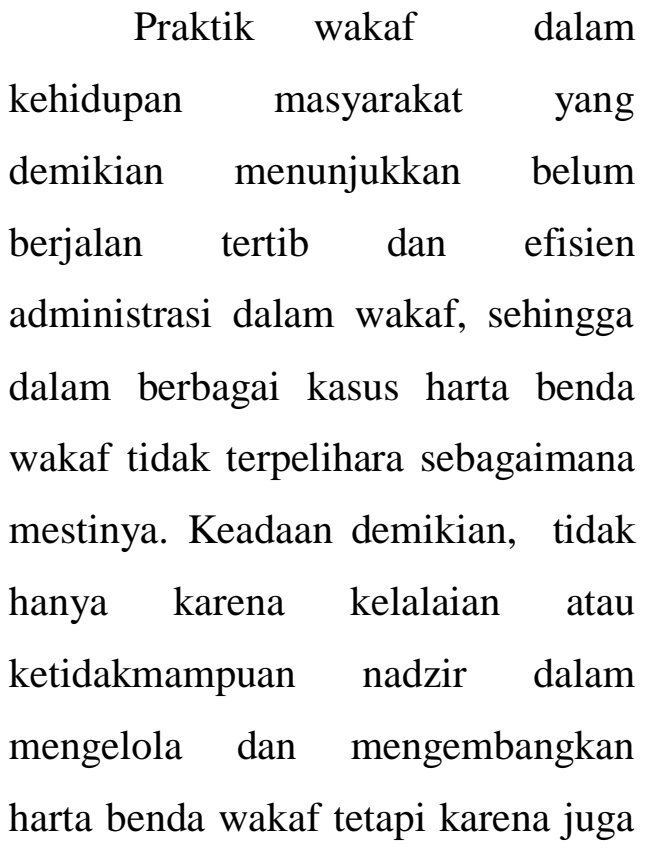


sikap masyarakat yang kurang peduli atau belum memahami status harta benda wakaf yang seharusnya dilindungi demi untuk kesejahteraan umum sesuai dengan tujuan,fungsi,dan peruntukan wakaf. 2

Salah satu persengketaan tanah wakaf adalah yang berkaitan dengan waris, di mana tanah wakaf sebelumnya merupakan tanah warisan yang diwakafkan oleh wakif, akan tetapi terdapat permasalahan apabila tanah yang diwakafkan tersebut tidak diketahui oleh ahli waris, Wakaf juga kerap diminta kembali oleh ahli waris yang menyimpang dari akad wakaf, ahli waris mengingkari ikrar wakaf dan ahli waris tidak diberi tahu orang tuanya sehingga menjualnya.

Hukum kewarisan merupakan bagian dari hukum kekeluargaan yang memegang peranan penting, bahkan menentukan dan mencerminkan sistem kekeluargaan yang berlaku dalam masyarakat. Hukum kewarisan sangat erat

2 Taufik Hamami, Perwakafan Tanah (Dalam Politik Hukum Agraria Nasional), (Jakarta: Tatanusa, 2003), hlm. 3 hubungannya dengan kehidupan manusia karena terkait dengan harta kekayaan dan manusia yang satu dengan yang lainnya. Kematian atau meninggal dunia adalah peristiwa yang pasti akan dialami oleh seseorang, karena kematian merupakan akhir dari perjalanan hidup seorang manusia. Jika orang yang meninggal dunia yang dikenal dengan pewaris meninggalkan keluarga dan harta kekayaan yang disebut warisan, dengan cara apa kita akan dapat diselesaikan atau dibagi warisan yang ditinggalkan oleh pewaris serta hukum apa yang akan diterapkan untuk membagi warisan tersebut. Hukum yang membahas tentang peralihan harta peninggalan, pengurusan dan kelanjutan hak-hak dan kewajiban seseorang yang meninggal dunia, diatur dalam hukum kewarisan.

Agama Islam mengatur cara pewarisan itu berasaskan keadilan antara kepentingan anggota keluarga, kepentingan agama dan kepentingan masyarakat. Hukum Islam tidak hanya memberi warisan kepada pihak suami atau isteri saja, tetapi juga memberi warisan kepada 
keturunan kedua suami isteri itu, baik secara garis lurus ke bawah, garis lurus ke atas, atau garis ke samping, baik laki-laki atau perempuan, melalui alasan demikian maka hukum kewarisan Islam bersifat individual.

Wakaf dalam perspektif fikih didefinisikan sebagai perbuatan hukum menahan benda yang dapat diambil manfaatnya tanpa menghabiskan bendanya untuk digunakan di jalan kebaikan. Hak milik berupa materi yang telah diwakafkan dianggap sebagai milik Allah yang harus dimanfaatkan untuk kepentingan masyarakat sesuai dengan tujuan wakaf. $^{3}$ Dalam praktiknya pengambilalihan tanah wakaf yang batal dalam hukum untuk dibagikan sebagai waris banyak terjadi penyimpangan, jika ditinjau dalam Hukum Islam perlunya ikrar wakaf dan pembagian waris dulu sebelum di wakafkan.".Pasal 1 butir 1 UndangUndang Nomor 41 Tahun 2004 tentang Wakaf dinyatakan bahwa

\footnotetext{
3) Abdul Ghofur Anshori, Hukum dan Praktek Perwakafan di Indonesia, (Yogyakarta: Pilar Media, 2006), hlm.24.
}

wakaf adalah perbuatan hukum wakif untuk memi-sahkan dan/atau menyerahkan sebagian harta benda miliknya untuk dimanfaatkan selamanya atau untuk jangka waktu tertentu sesuai dengan kepentingannya guna keperluan ibadah dan/atau kesejahteraan umum menurut syariah.

\section{B. Perumusan Masalah}

1. Bagaimana proses pengambilalihan tanah wakaf yang batal dalam hukum untuk dibagikan sebagai harta warisan?

2. Bagaimana kedudukan hukum pengambilalihan tanah wakaf yang batal dalam hukum untuk dibagikan sebagai harta warisan berdasarkan Undang-undang Nomor 41 Tahun 2004 tentang wakaf?

\section{Tujuan Penelitian}

1. Untuk memahami proses pengambilalihan tanah wakaf yang batalk dalam hukum untuk dibagikan sebagai harta warisan.

2. Untuk memahami kedudukan hukum pengambilalihan tanah wakaf yang batal dalam hukum untuk dibagikan sebagai harta 
warisan berdasarkan Undangundang Nomor 41 Tahun 2004 tentang wakaf.

\section{Metode Penelitian}

\section{Metode Pendekatan}

Metode penelitian yang digunakan dalam penelitian ini adalah pendekatan yuridis normatif.

\section{Spesifikasi Penelitian}

Spesifikasi penelitian yang digunakan dalam penelitian ini adalah deskriptif analitis. yang menggambarkan mengenai permasalahan dalam penelitian sesuai dengan riset yang berlangsung dan untuk memeriksa sebab-sebab mengapa permasalahan terjadi. Dalam penelitian ini yaitu mengenai kedudukan hukum pengambilalihan tanah wakaf yang batal dalam hukum untuk dibagikan sebagai harta warisan berdasarkan UndangUndang Nomor 41 Tahun 2004 tentang wakaf.

\section{Sumber Data}

Sumber data dalam usulan penelitian ini menggunakan data sekunder, yaitu data yang diperoleh dari buku atau literatur melalui studi kepustakaan karena berdasarkan dokumen atau literatur-literatur yang berkaitan dengan tanah wakaf dan harta warisan.

\section{Teknik Pengumpulan Data}

Teknik pengumpulan data yang digunakan oleh penulis adalah data data sekunder yaitu melalui studi kepustakaan. Dalam penelitian ini di kelompokkan menjadi 3 (tiga) yaitu. : ${ }^{4}$

1) Bahan Hukum Primer, yaitu bahan yang mengikat, terdiri dari

a) Undang-Undang Dasar 1945

b) Undang-Undang Nomor 5 Tahun 1960 tentang Peraturan Dasar PokokPokok Agraria (UUPA)

c) Undang-Undang Republik Indonesia Nomor 41 Tahun 2004 tentang wakaf.

2) Bahan Hukum Sekunder, yaitu data yang berasal dari bahan pustaka yang berhubungan dengan obyek penelitian antara lain berupa buku-buku, dokumen

${ }^{4}$ Soerjono Soekanto, Pengantar Penelitian Hukum, (Jakarta : UI Press, 2007), hlm. 196 
dan publikasi yang berkaitan dengan masalah yang diteliti.

3) Bahan Hukum Tersier, yaitu bahan-bahan yang memberikan informasi tentang bahan hukum primer dan bahan hukum sekunder, misalnya : bibliografi (daftar sumber bacaan).

\section{Metode Analisis Data}

Metode yang digunakan adalah analisis kualitatif, yaitu data yang diperoleh dari studi kepustakaan atau data sekunder kemudian disusun secara sistematis, dan selanjutnya dianalisa secara kualitatif untuk mencapai kejelasan masalah yang akan dibahas. Data tersebut kemudian dianalisa secara interpretatif menggunakan teori maupun hukum positif yang telah dituangkan kemudian secara deduktif ditarik kesimpulan untuk menjawab permasalahan yang ada.

\section{HASIL PENELITIAN DAN \\ PEMBAHASAN}

\section{A. Proses pengambilalihan tanah} wakaf yang batal demi hukum untuk dibagikan sebagai harta warisan.

Masalah perwakafan saat ini tidak hanya menyangkut masalah dibidang keagamaan Islam belaka, namun kini menyangkut pelaksanaan tugas-tugas keagrariaan sehingga wakaf sebagai sebuah lembaga keagamaan yang dapat dipergunakan sebagai salah satu sarana guna pengembangan kehidupan beragama, khususnya bagi umat yang beragama Islam. ${ }^{5}$ Hukum Islam tidak ada ketentuan khusus yang mengharuskan pendaftaran tanah wakaf, apalagi pensetifikasian tanah wakaf karena memang dalam Islam sendiri praktek wakaf sudah dianggap sah apabila telah memenuhi rukun dan syaratnya, ${ }^{6}$ tanpa adanya syarat-syarat administrasi seperti yang dimaksud dan dituntut dalam hukum positif Indonesia, yaitu Undang-Undang No. 41 Tahun 2004 tentang wakaf.

Pengambilalihan tanah wakaf yang telah diwakafkan telah secara tegas dan nyata tidak dibenarkan dan dilarang menurut

\footnotetext{
5 Rachmadi Usman, Hukum Perwakafan di Indonesia, (Jakarta: Sinar Grafika, 2009), hlm. 119

6 Departemen Agama RI, Fiqih Wakaf, (Jakarta: Direktorat Pemberdayaa Wakaf, Dirjen Bimas Islam, Depag RI, 2006), hlm. 21
} 
peraturan perundang-undangan perwakafan yang berlaku, dalam hal ini tercantum dalam Pasal 3 UndangUndang Nomor 41 Tahun 2004 Tentang Wakaf yang menyatakan bahwa wakaf yang telah diikrarkan tidak dapat dibatalkan atau tidak dapat dilakukan pengambilalihan kembali.

Dalam Undang-undang No. 41 Tahun 2004 tentang Wakaf disebutkan bahwa penyelesaian sengketa perwakafan ditempuh melalui musyawarahuntuk mencapai mufakat. Namun apabila penyelesaian sengketa tidak berhasil, sengketa dapat diselesaikan melalui mediasi, arbitrase, atau pengadilan. Penyelesaian perselisihan yang menyangkut persoalan kasus-kasus harta benda wakaf diajukan kepada Pengadilan Agama dimana harta benda wakaf dan Nazhir itu berada, sesuai dengan ketentuan peraturan perundang-undangan yang berlaku. Dengan demikian, jelaslah masalahmasalah lainnya yang secara nyata menyangkut Hukum Perdata, sedangkan yang terkait dengan perbuatan hukum pidana diselesaikan melalui hukum acara dalam
Pengadilan Negeri. Selain masalah penyelesaian sengketa, Undangundang Wakaf juga mengatur ketentuan pidana umum terhadap penyimpangan terhadap benda wakaf dan pengelolaannya sebagai berikut:

a. bagi yang dengan sengaja menjaminkan,

menghibahkan, menjual, mewariskan, mengalihkan dalam bentuk pengalihan hak lainnya tanpa izin di pidana penjara paling lama 5 (lima) tahun dan/atau pidana denda paling banyak $\mathrm{Rp}$ 500.000.000,00 (lima ratus juta rupiah).

b. bagi yang dengan sengaja mengubah peruntukan harta benda wakaf tanpa izin di pidana penjara paling lama 4 (empat) tahun dan/atau pidana denda paling banyak Rp 400.000.000,00 (empat ratus juta rupiah).

c. bagi yang dengan sengaja menggunakan atau mengambil fasilitas atas hasil pengelolaan dan pengembangan harta benda wakaf melebihi jumlah yang 
ditentukan, dipidana dengan pidana penjara paling lama 3 (tiga) tahun dan/atau pidana denda paling banyak Rp300.000.000,00 (tiga ratus juta rupiah).

Ketentuan pidana merupakan suatu suatu keharusan dalam sebuah peraturan perundangan yang mengatur tentang suatu persoalan di negara kita. Dalam sebuah undangundang harus mencantumkan ketentuan khusus mengenai sanksi pidana sebagai penguat dan jaminan agar supaya peraturan dimaksud dilaksanakan sebagaimana mestinya. Namun, untuk memaksimalkan peran Peradilan Agama, nampaknya perlu difungsikan sebagai Peradilan Syari'ah bagi setiap warga negara pemeluk agama Islam dalam kaca mata pemahaman yang komprehensif. Dalam kedudukannya di atas, Peradilan Agama harus diberdayakan sebagai payung hukum bagi umat Islam dalam penyelesaian semua kasus-kasus perdata dan pidana yang berkaitan dengan hukum muamalat. Peran dan fungsi serta wewenang Peradilan Agama dari waktu ke waktu harus ditingkatkan sejalan dengan perkembangan hukum dan kemasyarakatan. Apalagi status Pradilan Agama saat ini telah digabungkan satu atap dengan Mahkamah Agung Republik Indonesia. Selain pengawasan yang bersifat umum berupa payung hukum yang memberikan ancaman terhadap pihak yang melakukan penyelewengan dan atau sengketa berkaitan dengan pengelolaan harta wakaf, upaya pengawasan benda wakaf dapat langsung dilakukan oleh pihak pemerintah dan masyarakat. Sebagaimana yang termuat dalam Bab VII Undang-undang No. 41 Tahun 2004 tentang Wakaf yang menyebutkanbahwa Menteri (agama) melakukan pembinaan dan pengawasan terhadap penyelenggaraan wakaf untuk mewujudkan tujuan dan fungsi wakaf dengan mengikutsertakan Badan Wakaf Indonesia BWI dengan tetap memperhatikan saran dan pertimbangan Majelis Ulama Indonesia.

Dalam melaksanaan tugas pembinaan, Menteri dan BWI dapat melakukan kerja sama dengan organisasi masyarakat, para ahli, 
badan internasional, dan pihak ain yang dipandang perlu. Sedangkan dalam menjalankan pengawasan, Menteri dapat menggunakan akuntan publik.

Peran pemerintah yang memiliki akses birokrasi yang sangat luas dan otoritas dalam penegakan hukum merupakan aspek penting dalam melindungi eksistensi dan pengembangan wakaf secara umum. Demikian juga masyarakat sebagai pihak yang berkepentingan langsung terhadap pemanfaatan harta-harta wakaf dapat mengawasi secara langsung terhadap jalannya pengelolaan wakaf. Tentu saja pola pengawasan yang bisa dilakukan oleh masyarakat bukan bersifat interventif (campur tangan manajemen), namun memantau, baik langsung maupun tidak langsung terhadap pola pengelolaan dan pemanfaatan wakaf itu sendiri. Sehingga peran lembaga Nazhir lebih terbuka dalam memberikan laporan terhadap kondisi dan perkembangan harta wakaf yang ada. Untuk itu, agar pengelolaan wakaf dapat lebih bisa dipertanggungjawabkan oleh lembaga Nazhir yang ada kepada pemerintah dan masyarakat umum, diperlukan upaya perwujudan sebuah kondisi sebagai berikut :

Pertama, gerakan untuk mempelopori transparansi dalam semua aspek kelembagaan Nazhir, baik dalam lingkup internal maupun eksternal. Adanya transparans kelembagaan Nazhir ini merupakan jihad yang bersifat sistemik untuk menutup tindakan ketidakjujuran, korupsi, manipulasi dan lain sebagainya. Transparansi adalah aspek penting yang tak terpisahkan dalam rangkaian menegakkan amanah perwakafan yang diajarkan oleh nilai-nilai Islam. Sehingga lembaga wakaf dalam Islam bisa dijadikan tolak ukur keterbukaan dalam mengemban tanggung jawab moral para Nazhir menuju tatanan hidup bermasyarakat yang berkeadaban dan berkeadilan semesta.

Kedua, lembaga Nazhir harus mempelopori sistem public accountability. yaitu mendorong terjadinya iklim akuntabilitas publik dalam pengelolaan harta wakaf. Pertanggungjawaban umum 
merupakan wujud dari pelaksanaan sifat amanah (kepercayaan) dan shidiq (kejujuran). Karena kepercayaan dan kejujuran memang harus dipertanggungjawabkan, baik di dunia maupun di akhirat kelak. Sehingga dengan demikian, wakaf dapat dijadikan wahana yang sangat menjanjikan untuk kepentingan kesejahteraan masyarakat yang kredibel (sangat dipercaya) dengan tetap menjunjung tinggi nilai profesionalisme kerja yang beretos kerja baik.

Ketiga, lembaga Nazhir mempelopori gerakan yang aspiratif. Orang-orang yang terlibat dalam kelembagaan Nazhir harus mendorong terjadinya sistem sosial yang melibatkan partisipasi banyak kalangan. Hal ini dilakukan untuk menghindari terjadinya pola pengambilan keputusan secara sepihak oleh kalangan elit kepemimpinan di dalam lembaga keNazhiran. Sehingga upaya tersebut dapat mengurangi, bahkan menutup potensi-potensi yang berkembang, yang bisa jadi-mungkin jauh lebih baik atau sempurna. Kaedah prinsip dalam gerakan yang aspiratif merupakan cermin dari sifat adil dalam diri atau lingkungannya. Dengan demikian, kalau lembaga Nazhir mau, mampu dan konsisten (istiqamah) memperjuangkan dan mempelopori ketiga aspek upaya pengawasan tersebut, niscaya masyarakat akan merasakan pentingnya lembaga wakaf dalam kehidupan masyarakat. Sehingga, kalau selama ini lembaga Nazhir terkenal dengan ketidakprofesionalan dan ketidakamanahan terhadap hartaharta wakaf yang dipercayakan kepadanya akan terkubur dengan sendirinya. Dan pada saatnya nanti, wakaf menjadi jawaban yang paling konkrit terhadap problem-problem sosial demi menciptakan kesejahteraan di dunia dan akhirat

Pada pasal 50 Undangundang Nomor 3 Tahun 2006 dinyatakan pula bahwa; (1) Dalam hal terjadi sengketa hak milik atau sengketa lain dalam perkara sebagaimana dimaksud dalam pasal 49, khusus mengenai objek sengketa tersebut harus diputus lebih dahulu oleh pengadilan dalam lingkungan Peradilan Umum. (2) Apabila terjadi sengketa hak milik sebagaimana 
dimaksud pada ayat (1) yang subjek hukumnya antara orang-orang yang beragama Islam, objek sengketa tersebut diputus oleh pengadilan agama bersama-sama perkara sebagaimana dimaksud dalam pasal 49. Penjelasan pasal 50 ayat (2) Undang-undang Nomor 3 Tahun 2006 menyebutkan bahwa "ketentuan ini memberi wewenang kepada pengadilan agama untuk sekaligus memutuskan sengketa milik atau keperdataan lain yang terkait dengan objek sengketa yang diatur dalam pasal 49 apabila subjek sengketa antara orang-orang yang beragama Islam"

Gugatan para ahli waris yang meminta kepada Pengadilan Agama Semarang untuk melaksanakan pengambilalihan tanah wakaf yang pada akhirnya dikabulkan oleh Pengadilan Agama Semarang karena pelaksanaan perwakafan tidak memenuhi syarat-syarat sahnya perwakafan. Diantaranya jika ditinjau dari sudut pandang UndangUndang Wakaf Nomor 41 Tahun 2004 bahwasannya pelaksanaan wakaf tidak memenuhi diantaranya adalah tidak dilaksanakannya ikrar wakaf dan harta wakaf masih berstatus sengketa antar para ahli waris dan merupakan harta bersama wakif dengan istri pertama dan istri kedua yang belum dibagi waris Pembagian warisan harus dipisahkan terlebih dahulu antara harta warisan dengan harta bersama wakif dengan istri-istrinya. Sesuai Pasal 97 Kompilasi Hukum Islam (KHI) bahwa pasangan yang hidup lebih lama (duda/janda) berhak mendapatkan seperdua dari harta bersama, sehingga Majelis hakim menetapkan setengah dari harta bersama adalah harta wakif yang belum dibagi waris.

\section{B. Kedudukan}

hukum pengambilalihan tanah wakaf yang batal demi hukum untuk dibagikan sebagai harta warisan berdasarkan Undangundang Nomor 41 Tahun 2004 tentang wakaf.

$$
\text { Berdasarkan Pasal } 40
$$
Undang-Undang Nomor 41 tahun 2004 tentang Wakaf, dinyatakan bahwa :

$$
\begin{aligned}
& \text { "Harta benda Wakaf yang } \\
& \text { sudah diwakafkan dilarang }
\end{aligned}
$$


dialihkan dalam bentuk jaminan dan kepastian hukum pengalihan hak lainnya". mengenai tanah yang telah Perubahan wakaf tidak dapat diwakafkan kepadanya. Untuk dilakukan, artinya benda atau barang yang sudah diwakarkan tidak dapat dialihkan haknya, akan tetapi yang dapat dialihkan adalah pemanfaatan wakaf. Misalnya semula untuk sekolah oleh yayasan penerima wakaf, kemudian digunakan juga untuk mendirikan universitas karena dianggap tidak bertentangan dengan hukum Islam dan peraturan perundang-undangan yang berlaku.

Penggunaan tanah wakaf selama tidak merubah peruntukan wakaf secara signifikan sebagaimana dimaksud oleh waqif, apalagi bila lebih bernilai produktif dan masih dalam lingkup kesejahteraan umum. Permasalahan yang sering terjadi adalah peralihan yang tidak murni atau bahkan pembatalan wakaf.

Fungsi pendaftaran tanah wakaf pada pokoknya adalah untuk memperoleh jaminan dan kepastian hukum mengenai tanah yang diwakafkan. Apabila sertipikat tanah telah dibalik nama atas nama nazhir dengan dibuatkan sertipikat wakaf maka nazhir akan memperoleh menjamin kepastian hukum hak atas tanah wakaf, UUPA telah menentukan adanya pendaftaran tanah di seluruh wilayah Republik Indonesia sebagaimana dinyatakan dalam Pasal 19 ayat 1 UUPA No. 5 Tahun 1960 yang berbunyi :

"Untuk menjamin kepastian hukum oleh Pemerintah diadakan pendaftaran tanah di seluruh wilayah Republik Indonesia menurut ketentuan yang diatur oleh Peraturan Pemerintah. Sedangkan cara pendaftaran tanah wakaf yang terjadi sebelum berlakunya Peraturan Pemerintah Nomor 28 Tahun 1977 tentang Perwakafan Tanah Milik, dilakukan sebagaimana Peraturan Menteri Agama Nomor 1 Tahun 1978, yakni setelah tanah wakaf tersebut diditerbitkan ,Akta Pengganti Ikrar Wakaf oleh PPAIW yang bersangkutan."

Pasal 3 UU No. 41 Tahun 2004 tentang Wakaf, bahwa Wakaf 
yang telah di ikrarkan tidak dapat dibatalkan. Jadi pada dasarnya Akta Ikrar Wakaf tidak dapat dibatalkan kecuali ada sesuatu hal yang dapat membatalkannya, seperti mewakafkan tanah yang tidak dilakukan oleh keseluruhan ahli warisnya. Perwakafan tanah ini terjadi pada tahun 1970 kurang lebih sudah 42 tahun terhitung sejak terbitnya Akta Pengganti Akta Ikrar Wakaf .

Demikian pula halnya apabila Pasal 7 ayat (2) KHI dianalogikan kepada Isbat Wakaf, maka obyek wakaf bila tidak ada AIW-nya, seharusnya dapat juga mengajukan Isbat Wakaf ke Pengadilan Agama setempat. Dan untuk menyempurnakan kewenangan Peradilan Agama dalam mengadili perselisihan tentang benda wakaf dan na<z\}hir, perlu disiapkan peraturan perundang-undangan yang mengatur dan memberikan kewenangan voluntair (Isbat Wakaf ) kepada lembaga Pengadilan Agama.

Hakim sebagai penentu dari para pencari keadilan harus bisa memberikan suatu putusan perkara sesuai dengan fakta-fakta yang ada

dan di sesuaikan dengan undangundang yang berlaku serta kemaslahatan bagi pihak berperkara. Pada surat Al Baqarah ayat 282 dan beberapa kaidah fiqhiyyah sebenarnya menyiratkan pencatatan dan pengadministrasian tanah wakaf adalah sangat dianjrkan dan dapat disimpulkan bahwa berdasarkan alasan tersebut, tanah wakaf yang tidak dicatatkan dan didaftarkan adalah tidak sah menurut ketentuan tersebut. Berdasarkan pemikiran tersebut maka status tanah wakaf tanpa sertipikat menurut hukum Islam sejauh sudah terdaftar dan tercatat pada instansi yang erwenang maka tanah terebut telah memiliki kekuatan dimata hukum. Senada dengan Undang-Undang Nomor 41 Tahun 2004, tanah wakaf adalah sah apabila telah dicatatkan dan didaftarkan. Adapun mengenai apakah tanah tersebut sudah memiliki sertipikat tanah wakaf atau belum dalam undang-undang tidak dibahas, apalagi dalam hukum Islam.

Undang-undang wakaf
menjelaskan bahwa wakaf
dinyatakan sah dan legal dalam arti
mempunyai kekuatan hukum apabila


telah diikrarkan dan didaftarkan menurut mekanisme dan peraturan yang berlaku, dalam hal ini adalah Undang-undang Nomor 41 Tahun 2004 tentang wakaf. Tata cara pendaftaran tanah wakaf menurut UU dan prosedur yang berlaku, seperti yang telah dijelaskan adalah:

a. Telah melakukan Ikrar Wakaf di hadapa pejabat pembuat akta ikrar wakaf (PPAIW), dalam hal ini adalah pegawai KUA setempat. Selanjutnya dalam UU Nomor 41 Tahun 2004 diatur dan dijelaskan mengenai ikrar wakaf dalam bagian ketujuh Pasal 17, 18, 19, 20 dan Pasal 21.

b. Setelah melakukan ikrar wakaf di depan PPAIW maka langkah selanjutnya sesuai dengan UU ini adalah PPAIW atas nama nadzir mendaftarkan harta benda wakaf kepada instansi yang berwenang paling lambat 7 (tujuh) hari sejak akta ikrar wakaf ditandatangani. Hal ini diatur dalam pasal 32 . Dalam hal pendaftaran harta benda wakaf sebagaimana dimaksud dalam Pasal 32, PPAIW menyerahkan: salinan akta ikrar wakaf dan surat-surat dan/atau bukti-bukti kepemilikan dan dokumen terkait lainnya. Sebagaimana diatur dalam pasal 33, selanjutnya ketentuan ini juga tercantum dalam Pasal 34, 35, 36, 38 dan 39 UU No. 41 Tahun 2004 tentang wakaf. ${ }^{7}$

Di dalam UU tentang wakaf tidak dibahas mengenai sertifikasi tanah wakaf, sementara selain tata cara pendaftaran tanah wakaf, tata cara pensertifikasian tanah wakaf juga perlu karena menyangkut aspek legal hukum dari segi agrarian tanah wakaf tersebut. Tidak dibahasnya mengenai sertifikat tanah wakafitu dikarenakan sertifikasi tanah wakaf merupakan satu kesatuan yang tidak terpisahkan dalam pencatatan dan pendaftaran tanah wakaf, dengan kata lain tidak mungkin terbit sertipikat tanah wakaf sebelum tanah wakaf tersebut didaftarkan ke instansi yang berwenang dalam hal ini adalah KUA yang mewilayahi lokasi dari tanah tersebut.

7 Departemen Agama RI, Peraturan Perundang-undangan, (Jakarta: Direktorat Pemberdayaa Wakaf, Dirjen Bimas Islam, Depag RI, 2006), hlm. 17 
Berkaitan dengan tanah Radbruch, yang menyebutkan wakaf yang belum memiliki terdapat dua macam pengertian sertipikat tanah wakaf, undang- kepastian hukum, yaitu kepastian undang mendasarkannya pada hukum oleh hukum dan kepastian hukum Islam. Pada masa dahulu, hukum dalam atau dari hukum. wakaf secara hukum Islam dikatakan sah apabila sudah memenuhi syarat dan rukunnya, terlepas apakah dicatatkan atau tidak pada instansi yang berwenang, karena memang dalam hukum Islam sendiri tidak diharuskan adanya pencatatan dan pendaftaran tanah wakaf.

Pada prakteknya mayoritas umat Islam Indonesia melakukan praktik wakaf seperti yang dikatakan di atas (tanpa pencatatan dan pendaftaran), maka akibatnya banyak tanah wakaf yang disalahgunakan karena memang tidak ada ukti otentik bahwa tanah tersebut adalah tanah wakaf. Oleh karena itu lahirlah beberapa peraturan perundangan yang mengatur tentang permasalahan wakaf. Terbaru adalah UndangUndang Nomor 41 Tahun 2004 tentang wakaf. Yang memberikan aspek kepastian hukum dalam kedudukan wakaf yang batal dalam hukum, kepastian ini seperti halnya yang disampaikan oleh Gustav 
yang diatur dalam perundangundangan yang mengatur mengenai wakaf.

\section{PENUTUP}

\section{A. Simpulan}

1. Proses pengambilalihan tanah wakaf yang batal dalam hukum untuk dibagikan sebagai harta warisan dilaksanakan oleh Pengadilan Agama Semarang yaitu dengan menetapkan harta bersama wakif dengan istri wakif, selanjutnya menetapkan setengah dari harta bersama tersebut adalah bagian wakif yang belum dibagi waris sekaligus menetapkan para ahli waris dan bagian-bagiannya menurut pembagian pewarisan Islam. Hal ini sesuai dengan Pasal 97 Kompilasi Hukum Islam yang menyatakan bahwa wakif (duda) berhak atas seperdua dari harta bersama sepanjang tidak ditentukan lain dalam perjanjian perkawinan.

2. Kedudukan hukum pengambilalihan tanah wakaf yang batal dalam hukum untuk dibagikan sebagai harta warisan berdasarkan Undangundang Nomor 41 Tahun 2004 tentang wakaf, Pada prinsipnyua UU No.41 Tahun 2004 menegaskan bahwa tanah wakif yang sudah diwakafkan tidak bisa dibatalkan, namun tentunya pronsip kepastian hukum tersbut harus bersinergi trerhadap nilai keadilankepada pewakif atau ahli waris . Di sinilah peran hakim dituntut memberikan keadilan yang seadilnya jika ditemukan masalah.

\section{B. Saran}

1. Bagi Pemerintah Perlunya sosialisasi huokum perwakafan di masyarakat mengenai kriteria tanah yang harus diwalafkan dan yang diwariskan agar tidak terjadi sengketa wakaf di kemudian hari.

2. Bagi Penegak Hukum termasuk nadzir 
Diharapkan memberikan materi kepastian, keadilan dan kemamanfaatan terhadap proses wakaf yang batal dalam hukum, serta bisa menjadi patokan penyelesaian yang terkait pengambilalihan tanah wakaf yang dalam sengketa wakaf di kemudian hari.

3. Bagi Masyarakat

Dapat merespon dan memahami aturan normative UU wakaf sehingga pelaksanaan wakaf sesuai dengan peraturan perundang-undangan yang berlaku.

\section{DAFTAR PUSTAKA}

\section{Buku-buku}

Abdul Ghofur Anshori, Hukum dan Praktek Perwakafan di Indonesia, Yogyakarta: Pilar Media, 2006

Abdurrahman, Masalah Perwakafan Tanah Milik dan Kedudukan Tanah Wakaf di Negara Kita, Bandung: Citra Aditya Bakti, 1994

Achmad Ali, Menguak Teori Hukum (Legal Theory) dan Teori Peradilan (Judicial Prudence) Termasuk Interpretasi Undang-Undang (Legisprudence), (Jakarta :
Kencana Prenada Media Group, 2009

Departemen Agama RI, Fiqih Wakaf, Jakarta: Direktorat Pemberdayaa Wakaf, Dirjen Bimas Islam, Depag RI, 2006

Departemen Agama RI, Peraturan Perundang-undangan,

Jakarta: Direktorat Pemberdayaa Wakaf, Dirjen Bimas Islam, Depag RI, 2006

Departemen Agama, Himpunan Peraturan Perundangundangan Perwakafan Tanah Milik, Jakarta: Bag. Proyek Peningkatan Zakat dan Wakaf, 2012

Rachmadi Usman, Hukum Perwakafan Di Indonesia), Jakarta: Sinar Grafika, 2009

Ronny Hanitijo Soemitro, Metode Penelitian Hukum, Jakarta : Ghalia Indonesia, 1995

Soerjono Soekanto dan Sri Mamudji, Penelitian Hukum Normatif, Jakarta: Rajawali Press, 2006

Soerjono Soekanto, Pengantar Penelitian Hukum, Jakarta : UI Press, 2007

Taufik Hamami, Perwakafan Tanah (Dalam Politik Hukum Agraria Nasional), Jakarta: Tatanusa, 2003

\section{Undang-undang dan Peraturan- peraturan:}

Undang- Undang Dasar 1945 

Undang-Undang Nomor 5 Tahun 1960 tentang Pokok-pokok Agraria
Undang-Undang Nomor 41 Tahun 2004 tentang Wakaf
Peraturan Pemerintah Nomor 24 Tahun 1997 tentang Pendaftaran Tanah

Instruksi Presiden Nomor 1 Tahun 1991

Kompilasi Hukum Islam

PMA Nomor 73/2013 Pasal 24

\section{Website}

Kepastian Hukum Kepastian

Hukum", http://www.surabay apagi.com, diakses tanggal 16 November 2016 